\title{
Natural toxins: environmental contaminants calling for attention
}

\author{
Hans Christian Bruun Hansen ${ }^{1 *}$, Klara Hilscherova $^{2}$ and Thomas D. Bucheli ${ }^{3}$
}

\begin{abstract}
Biosynthetic toxic compounds from plants and cyanobacteria constitute a chemically diverse family of at least 20,000 compounds. Recent work with natural toxin databases and toxin characterization shows that the majority of natural toxins are polar and mobile, with toxicity ranging from low to very high, while persistence is highly variable. Natural toxins may be produced in high quantities—some exceeding $10 \mathrm{~g} / \mathrm{m}^{2} /$ year-resulting in high environmental loads. Recent phytotoxin monitoring indicates that one or more natural toxin is always present in a surface water sample, but that concentrations are highly variable often with pulses during rain events. Phytotoxins belong to many classes, but often with flavonoids and alkaloids dominating. Likewise, advanced monitoring discovers a wide spectrum of cyanobacterial metabolites that are released directly into surface waters during water blooms. Except of the few known cyanobacterial toxins, we have very limited info regarding their environmental fate and toxicity.

The 16 papers in this article collection present examples of natural toxin occurrence, properties, fate and toxicity. The overarching conclusion is that natural toxins should be monitored and characterized regarding their risk potential, and that natural toxins of greatest expected risk should be evaluated as thoroughly as industrial xenobiotics. Cyanotoxins are well known water contaminants that should be removed for producing drinking water, while for phytotoxins the current knowledge base is very limited. We advocate to intensify research on natural toxins, and to address the evident knowledge gaps on natural toxin analysis/monitoring, physical-chemical properties and degradation/ pathways, transport modelling, and toxicity. The complex and dynamic interplays between biotic and site conditions such as vegetation, toxic plant densities, climate, soil types, nutrients and radiation, play decisive roles for both biotoxin formation and fate. Environmental and toxicological research in biosynthesized compounds extends beyond natural toxins, with important perspectives for risk assessment of biopesticides, growth regulators and biomedicine (or biologicals collectively) produced by plants and microorganisms.
\end{abstract}

\section{Poisonous food}

We are picky with what we eat and drink-for good reasons. We wisely avoid death cap mushroom, castor beans, and poison hemlock. Drinking water from a lake tainted green by cyanobacteria is a no-go. We will even be careful with green potatos, non-cooked chickpeas, beans and cassava due to their contents of glycoalkaloids, lectins and cyanogenic glycosides. These and many other organisms

\footnotetext{
*Correspondence: haha@plen.ku.dk

${ }^{1}$ Department of Plant and Environmental Sciences, University

of Copenhagen, Copenhagen, Denmark

Full list of author information is available at the end of the article
}

produce secondary metabolites that are strong poisons, also to humans. Ames et al. [1] estimated that $99.99 \%$ of dietary "pesticides" were of natural origin. There are more than 20,000 natural bioactive compounds that are toxic to humans covering a wide range of modes of action [2]. Some show low acute toxicity like the glycoalkaloids in potato or isoflavones in clover, medium toxicity as linamarin in cassava and coniin in poisonous hemlock, while some are very toxic like ricin in castor beans and the cyanotoxin saxitoxin produced by blue-green algae (Table 1). Many of these compounds may have or have had a function as natural defense chemicals in order for the toxin producing organism to compete with other species,

\section{Springer Open}

(c) The Author(s) 2021. Open Access This article is licensed under a Creative Commons Attribution 4.0 International License, which permits use, sharing, adaptation, distribution and reproduction in any medium or format, as long as you give appropriate credit to the original author(s) and the source, provide a link to the Creative Commons licence, and indicate if changes were made. The images or other third party material in this article are included in the article's Creative Commons licence, unless indicated otherwise in a credit line to the material. If material is not included in the article's Creative Commons licence and your intended use is not permitted by statutory regulation or exceeds the permitted use, you will need to obtain permission directly from the copyright holder. To view a copy of this licence, visit http://creativecommons.org/licenses/by/4.0/. 
Table 1 Examples of natural phyto- and phycotoxins, properties and toxicity

\begin{tabular}{|c|c|c|c|c|c|c|}
\hline Toxin & Toxin class & Organism (example) & $\begin{array}{l}\text { Max tissue } \\
\text { conc. }^{a} \mathrm{mg} / \mathrm{g} \\
\text { DW }\end{array}$ & $\log K_{o w}^{b} L / L$ & Mode of toxicity & $\mathrm{LD}_{50}{ }^{\mathrm{c}} \mathrm{mg} / \mathrm{kg}$ \\
\hline Amanitin & Cyclo-peptide & Amanita phylloides & 3 & $<0$ & Hepatotoxin & 0.3 \\
\hline Ricin & Protein (lectin) & Ricinus communis & 32 & - & Cytotoxin & 0.02 \\
\hline Senecionine & Alkaloid & Jacobaea vulgaris & 7 & 1.90 & Hepatotoxic, potential carcinogen & 50 \\
\hline Coniin & Alkaloid & Conium maculatum & 4 & $2.6^{\text {est }}$ & Neurotoxin & 8 \\
\hline Solanine & Glycoalkaloid & Solanum tuberosum & 1 & $2.0^{\text {est }}$ & Cell membrane disruption & 30 \\
\hline Formononetin & Isoflavone & Trifolium pratense & 15 & $2.8^{\text {est }}$ & Estrogenic activity & - \\
\hline Linamarin & Cyanogenic glycoside & Manihot esculenta & 30 & $-1.4^{\mathrm{est}}$ & Cyanide poisoning & $1(\mathrm{HCN})$ \\
\hline Ptaquiloside & Terpenoide glycoside & Pteridium aquilinum & 15 & -0.6 & Carcinogen & - \\
\hline Microcystin LR & Cyclo-peptide & Microcystis aeruginosa & 13 & $-1.2(\mathrm{pH} 7)$ & Hepatotoxin & 0.06 \\
\hline Saxitoxin & Alkaloid & Dolichospermum circinale & 4.5 & $-2.4^{\text {est }}$ & Neurotoxin & 0.01 \\
\hline
\end{tabular}

${ }^{a}$ Max tissue concentration in the producing species: amanitin [73], ricin [74], senecionine [6], coniin [75], solanin [76], formononetin [77], linamarin [78], ptaquiloside [79], microcystin LR [80], and saxitoxin equivalent [81]

${ }^{\mathrm{b}}$ Estimated by EpiWin ( ${ }^{\text {est }}$ ) or literature data; senecionine [9], ptaquiloside [82], and microcystin LR [83]

${ }^{\mathrm{C}}$ Acute toxicity, intraperitoneal (mice); from inchem.org if not otherwise stated or literature; ricin [84], coniin [85], not acute toxic; formononetin EC ${ }_{50}$ in $\mu \mathrm{M}$ range [86], ptaquiloside estimated threshold conc. for $1: 10^{6}$ cancer incidence of arund $20 \mathrm{ng} / \mathrm{L}$ [82], saxitoxin [87], microcystin LR [88]; other microcystins [89]

and to protect itself against herbivoric and pathogenic attacks and other stressors $[3,4]$.

\section{High loads}

Many natural toxins are produced in remarkably high quantities with biomass contents up to several mass percent (Table 1). If plants occur as dense stands or in monocultures the production and hence the potential load per land area unit can be massive and much higher than seen for other land applied chemicals like pesticides. For instance a clover crop may produce isoflavones up to $220 \mathrm{~kg}$ per hectare annually [5], while quinolizidine alkaloids in lupin may reach annual production of $800 \mathrm{~kg}$ per hectare [6]. Bracken-a fern with invasive character-has been estimated to produce more than $20 \mathrm{~kg}$ of its carcinogenic illudane glycosides per hectare of land during a growing season [7]. The surface scums during massive cyanobacterial bloom events have been shown to reach maximum values over $100 \mathrm{mg} / \mathrm{L}$ of cyanotoxins microcystin [8].

\section{Environmental contaminants}

Natural toxins are biosynthesized and released within or in close proximity to surface water and groundwater reservoirs (Fig. 1). Thus, cyanobacterial blooms cause direct water contamination due to toxic secondary metabolites, while exudation from plants and rain wash off transfer toxins to soils from where they leach to surface waters and groundwater. A high fraction of natural toxins are polar and even charged, with octanol-water partition coefficients, $\log \mathrm{K}_{\mathrm{ow}}$, typically in the range from -5 to $3[9$, 10]. Hence, they are highly mobile in soils and sediments
(Table 1). In a pioneering work, Günthardt et al. [11] created a database of plants and their toxins for Central Europe. Starting with a set of 844 plants and 1586 toxins, the authors found that about a third of the toxins would classify as persistent, mobile and toxic (PMT) based on QSAR estimated properties. This work also showed that alkaloids make up the dominating class of plant PMT compounds. The Janssen group compiled a database for secondary metabolites from cyanobacteria with more than 2000 entries classified into 13 classes [12]. Cyanotoxins are not only microcystins but can cover a high variation in chemical diversity and share similar PMT properties as plant toxins. Work with the databases has demonstrated an embarrassing lack of experimental data on physical chemical properties, environmental fate and toxicity for most natural toxins, and points to the need of reference materials and analytical methods.

\section{They make it to the water}

With the large masses of toxins being produced combined with their inherent PMT properties, natural toxins are expected to be frequently observed in streams, rivers and lakes. Some cyanotoxins have been widely monitored showing their frequent occurrence in waterbodies with cyanobacterial blooms. The most commonly studied and detected cyanotoxin microcystin occurs on average in up to tens of ug/L levels in pelagic water outside scums, but its concentrations can be up to several orders of magnitude higher in surface blooms and scums $[8,13]$. Isoflavones originating from red clover or soybean dominated agricultural land occurred regularly in Swiss and US rivers in concentrations up to $217 \mathrm{ng} / \mathrm{L}[14,15]$. Mycotoxins, 


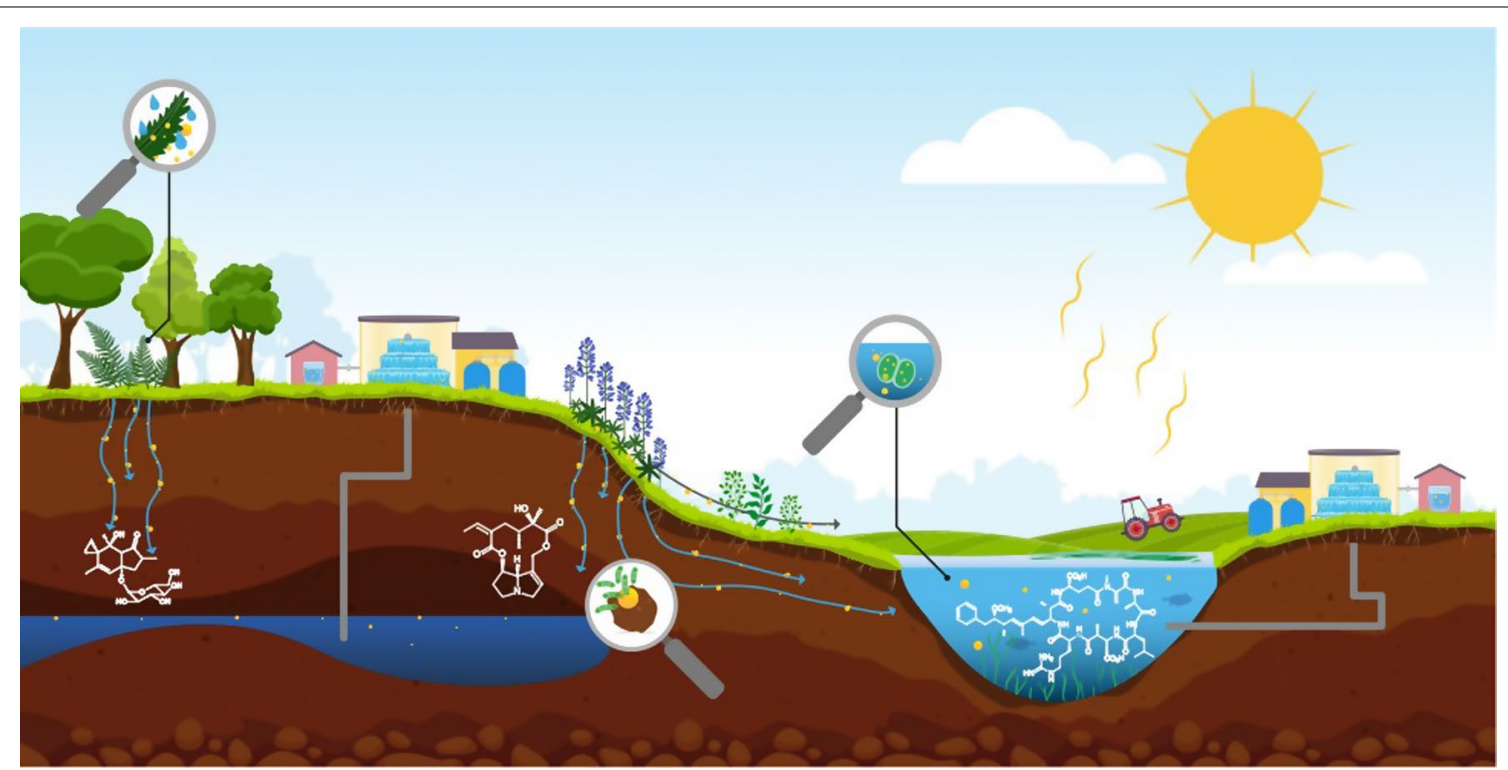

Fig. 1 Natural toxins from source to tap. Natural toxin (๑) production by cyanobacteria and plants (cropland, forests, pasture, gardens), release and transfer to lake water and soils, transport via soils to groundwater and surface water reservoirs from which drinking water is abstracted. Molecular structures of ptaquiloside (left), senecionine (middle) and microcystin LR (right) illustrating the polar nature of natural toxins (cf Table 1)

produced by Fusarium spp. that attack small grain cereals during cultivation, were equally found in these surface waters [16-18]. More recently, a growing body of evidence for the presence of a larger number of phytotoxins from various classes of secondary plant metabolites in groundand surface water was presented by various researchers in dedicated experimental field studies or surface water monitoring campaigns [6, 19-22]. Likewise, other types of natural compounds emitted primarily by the anthroposphere, such as food ingredients and personal care products, as well as human hormones are equally present in surface and groundwaters. Thus, caffeine, nicotine, estrogens, piperine, steroids and morphine occur frequently in screening studies of surface and groundwaters, e.g., [23-27].

Little is known on toxin transfer from plant to soil; passive and active release may take place both from aboveand below-ground parts. Field studies indicate that fast and substantial release of toxins may occur during rain events generating pulses of toxins that propagates through soils to drainage and creek waters $[5,28,29]$. Hence, natural toxin concentrations and exposure in surface waters and in upper groundwater may be highly variable over time. This in turn calls for rain-event and flow-proportional sampling as random sampling may not lead to precise estimates of environmental loads. The multitude of toxin producing organisms predicts that natural toxins in freshwaters should be found as mixtures with likely fingerprints of the dominating toxin producers in the catchment or the water reservoir [19]. Climate-induced change in cropping patterns, fast migration of new (invasive) species, faster development of cyanobacterial blooms and appearance of new toxin varieties add to the complexity, e.g., [30].

\section{Regulation, land management and water cleaning}

Natural toxins are not currently part of general drinking water assessment and regulation; only the cyanotoxin microcystin LR has been considered for inclusion in the EU Drinking Water Regulative [31], while WHO recently has published guideline values for cyanotoxins in drinking water and recreational exposure scenarios [32]. This is in strong contrast to food and feed where more natural toxins are regulated and regularly monitored, for instance pyrrolizidine alkaloids in tea and honey and aflatoxins in nuts and seeds [33-35]. More monitoring, fate and toxicological data are needed for risk assessment of natural toxins in drinking water, and to lay the foundation of a regulation.

Many actions can be taken to control the production of natural toxins and their concentrations in water reservoirs. Reducing eutrophication and algal blooms in river, lake and coastal waters via control of nitrate and phosphorus discharges from agriculture and with wastewater has high priority for reduction of cyanobacterial blooms, and remains as one of the major global sustainability goals [36]. Crops can be bred to produce less toxic varieties as for alkaloids in lupin, cyanogenic glycosides in cassava, isoflavones in red clover, and glucosinolates in rape seed, e.g., [37-39], which however also could make plants more susceptible to pathogenic attacks. Toxin producing plants 
in forests, grasslands and other non-cropped areas can be fought by burning, biological or chemical control or physically as practiced for bracken, ragwort, giant hogweed and Scotch broom, e.g., [40-42]. Finally, when natural toxins are already present in the water, they may be removed by water treatment at water works, e.g., by means of hydrolysis, microbial degradation in sand filters or advanced oxidation methods [43-45]. The major challenge is here for private and small scale water abstraction utilities that use water from smaller reservoirs and upper groundwaters, and employ no or very simple water treatment [46].

\section{Focus on safe water supply_papers in this article collection}

In 2020 an on-line conference "Natural Toxins-Environmental Fate and Safe Water Supply" was conducted to address knowledge gaps within the field of natural toxins and water quality (https://natoxaq.ku.dk/news/news-2016/ final-conference/). The conference was organized as part of the EU Marie Curie ITN project "Natural toxins and drinking water quality-from source to tap" (NaToxAq) (see Box). The present ESEU article collection comprises 16 papers almost equally distributed between cyanotoxins and plant toxins. A short introduction to the papers is given below.

\section{NaToxAq-fact box}

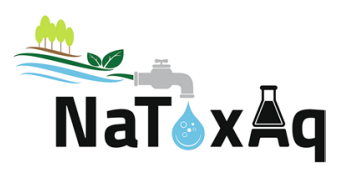

- Marie Curie ITN consortium 2017-2021 comprising 22 public and private partners in 7 European countries addressing water contamination by phyto- and phycotoxins.

- 16 Early Stage Researchers (ESRs)

- Work content:

- Analysis: target, non-target analysis, suspect screening, effect-directed analysis.

- Monitoring: sampling, groundwater/surface water, source allocation, toxin fingerprints, invasive species.

- Toxin phys-chem properties: sorption, degradation kinetics, metabolites, QSAR estimation, databases.

- Risk assessment and reduction: human toxicity, environmental modelling, risk communication, water treatment.

- Outputs and further information: -> https://natoxaq. ku.dk/. "Toxin of the week", 45 research papers, databases of phyto and phycotoxins/metabolites, reports and outreach.

\section{Cyanotoxins}

The papers concerned with cyanobacterial metabolites focus on the characterization of their mixtures in surface water bodies, their fate and stability in the environment, toxicity and hazard characterization as well as strategies for their mitigation. They bring novel information on a wide spectrum of compounds, including many understudied cyanobacterial peptides or retinoids produced by cyanobacterial water blooms.

Li et al. [47] assessed cyanobacterial risk in 108 Swedish lakes based on long term monitoring data. They documented that nutrients are main drivers for the higher cyanobacterial occurrence and also multispecies dominated water blooms in the affected lakes. They suggest to set nutrient targets to protect safe water supply and recreation. The study of Filatova et al. [48] documents a wide diversity of cyanopeptides in three freshwater reservoirs serving as drinking water resources in the U.K. The 28 identified cyanopeptides included microcystins, anabaenopeptins, aeruginosins, cyanopeptolins, microginins, some of them reported in UK waters for the first time. Natumi et al. [49] characterized environmental stability and photochemical fate of these, and also other cyanopeptides (54 total) from common water-bloom forming cyanobacteria under environmental conditions. Some of them were shown to be relatively stable and thus could potentially pose risk in drinking water resources.

Two studies bring information relevant for hazard assessment of selected cyanobacterial metabolites. Lovin et al. [50] observed species-specific responses in two of the most common larval fish models (zebrafish and fathead minnow) after exposure to neurotoxin anatoxina, with more pronounced sublethal effects in fathead minnows at environmentally relevant concentrations. Kubickova et al. [51] conducted an extensive review focused on retinoid compounds that can be also produced by cyanobacterial blooms. They summarized their sources, modes of action and potential adverse effects and discussed their implication for risk assessment. This paper also introduces the concept of cyanobacterial metabolites as anthropo-natural compounds, since they are produced by natural organisms, but anthropogenic impact causes their high concentrations.

Keliri et al. [52] investigated a methodology for bloom control by comparing the treatment efficiency of collected cyanobacterial bloom samples with liquid hydrogen peroxide or metallic peroxide granules slowly releasing oxidants. They emphasize the importance of correct dosing and timing of the treatment to avoid undesirable side-effects, including potential release of cyanotoxins into the waterbody. A comprehensive 
review by Schneider and Blaha [53] focuses on the applicability of advanced oxidation processes (AOP) during water treatment for removal of known cyanotoxins. It provides an overview of different AOP techniques that can be used for cyanotoxins degradation and the impact of technical parameters, toxin properties and water quality on its efficacy.

The cyanotoxin papers in this article collection bring novel information on some known cyanotoxins and mitigation of their presence, but also document that cyanobacterial metabolites comprise a much wider spectrum of compounds that can be released into surface waters during cyanobacterial water blooms. In contrast to relatively extensive literature on the few known cyanobacterial toxins, such as microcystins, we have only very limited information on many of the recently detected cyanobacterial metabolites. As documented by the included articles, some of them can be frequently present and highly relevant, but information on their occurrence, fate in the environment, stability and toxicity is largely missing.

\section{Plant toxins}

The papers presented in this issue on phytotoxins cover most of the well-established research domains in environmental chemistry. They range from investigations of specific environmental distribution and fate processes under laboratory conditions, over dedicated field experiments and monitoring campaigns in the real environment to effect studies and risk assessment.

Wu et al. [54] compared the stability of ptaquiloside in natural groundwater under environmentally relevant conditions with laboratory-based models and found a good agreement under slightly acid to neutral $\mathrm{pH}$. Under such conditions, ptaquiloside was found to prevail for months. Schönsee et al. [55] quantified sorption coefficients to clays and found that for cationic phytotoxins, in particular, a high proportion in soils may be attributed to these minerals. Field studies on production and occurrence of quinolizidine alkaloids and indole alkaloids from lupin, and of ptaquiloside from bracken fern were conducted by Hama and Strobel [56], and Garcia-Jorgensen et al. [7], respectively. Both types of phytotoxins were produced in considerable amounts, and could be quantified in soil pore waters in concentrations up to $4.8 \mu \mathrm{g} / \mathrm{L}$. Nanusha and co-workers screened German and Danish river waters for phytotoxins by both non-target and target analysis. They found thousands of overlapping peaks between water and plants from local vegetation [57], and detected 12 of 150 [58], and 27 out of 160 [59] targets (mostly for the secondary plant metabolite classes of alkaloids, coumarins and flavonoids), in concentrations up to $3 \mu \mathrm{g} / \mathrm{L}$. Groundwater monitoring with a focus on illudane glycosides (including again ptaquiloside) was carried out by Skrbic et al. [60]. No residues were found in deep groundwater wells, but for the first time, these compounds were detected in some private shallow wells. The fact that some phytotoxins are produced in high amounts, can be stable for months, mobile, and are found in soil pore water, river waters and drinking water resources asks for effect studies and (eco-)toxicological risk assessment. Griffiths et al. [61] contribute to the hitherto still very limited data and report $\mathrm{EC}_{50}$ values of alkaloids lupin and ragwort on Daphnia magna. According to them, there is a potential risk for aquatic organisms in stagnant pond water in vicinity of corresponding vegetation.

In summary, the compilation of papers presented here on phytotoxins in the environment adds considerably to the currently still rather limited literature. Their authors convincingly show that the topic is relevant, and that we may expect surface water samples in many situations to contain one or more natural toxins. Natural toxins show a high and fascinating diversity in terms of origin, environmental chemistry and (eco-)toxicology that goes beyond our traditional notion of (anthropogenic) environmental micropollutants. As such, they finally have truly emerged!

\section{The way forward}

In our strive to supply safe drinking water, to provide healthy recreational space, and to ensure stability and functioning of both cropped and non-cropped ecosystems, we should look at all relevant contaminants. Anthropogenic contaminants monitored in water quality assessments often have been found to add little to explain the toxicity profiles of natural water samples [62, 63]. Obviously, natural toxins add to the toxicity profiles but they are seldomly included among the compounds analysed. Thus, future water quality monitoring should include selected natural toxins/classes [64, 65]. The fast development of high-throughput non-target analytical techniques as well as effect-directed screening may help to accelerate more comprehensive monitoring schemes. Monitoring for natural toxins calls for more work on development of analytical methods and sample pretreatment, availability of reference substances and mass spectra as well as databases for toxin prioritization.

A high abundance of natural toxins in natural water samples may call for revision of current regulative water quality criteria with more emphasis on the total spectrum of contaminants in the samples and their inherent toxicities (incl. mixture toxicity) rather than working with fixed cut-off criteria for a defined set of anthropogenic chemicals, e.g., as used in the EU Drinking Water Regulative.

Natural bioactive compounds have a long history as (bio)pesticides and (bio)medicine (traditional medicine) or as templates for synthetic compounds [66, 
67]. Examples of biopesticides comprise pyrethrins extracted from chrysanthemum, the isoflavanoid rotenone from roots of certain legumes, and nicotine and strychnine alkaloids used as insecticide and molluscicide, respectively [68-71]. Plant-incorporated-protectants such as Bacillus thuringiensis (Bt) toxin in GMO crops have been successfully implemented but followed by numerous studies of environmental fate and effects of the Bt toxin on non-target organisms [72]. We are currently seeing a strong interest in use of natural bioactive compounds-or biologicals-as sustainable, low risk and climate-proof alternatives to synthetic chemicals. While biologicals are less regulated today, this is to come. This in turn will create a very strong push for further work on analysis, monitoring, fate, toxicity, and modelling of these myriads of bioactive natural compounds to ensure that proper risk assessments can be performed, but also to quantify the bioactivity, modes of actions and longevity of the biologicals in soils and other environmental compartments.

\section{Acknowledgements \\ We would like to acknowledge Angelika Lene Rasmussen for her work with typing and retrieving literature for the paper, and Westring, Copenhagen, for the graphics. This project has received funding from the European Union's Horizon 2020 research and innovation programme under the Marie Sklo- dowska-Curie Grant Agreement No. 722493 (NaToxAq).}

\section{Authors' contributions}

$\mathrm{KH}$ : commented on the layout, contributed to some sections of the manuscript, revised the text. TDB: assisted in the layout, contributed individual sections of the manuscript, revised the text. HCBH: Draft of the paper, outline of tables and figures, references and final editing. All authors read and approved the final manuscript.

\section{Availability of data and materials}

Not applicable.

\section{Declarations}

Ethics approval and consent to participate

Not applicable.

\section{Consent for publication}

Not applicable.

\section{Competing interests}

The authors declare that they have no competing interests.

\section{Author details}

'Department of Plant and Environmental Sciences, University of Copenhagen, Copenhagen, Denmark. ${ }^{2}$ Faculty of Science, RECETOX, Masaryk University, Brno, Czech Republic. ${ }^{3}$ Environmental Analytics, Agroscope, Switzerland.

Accepted: 11 August 2021

Published online: 29 September 2021

\section{References}

1. Ames BN, Profet M, Gold LS (1990) Dietary pesticides ( $99.99 \%$ all natural). Proc Natl Acad Sci 87(19):7777-7781. https://doi.org/10.1073/pnas.87.19. 7777
2. Teuscher E, Lindequist U (2010) Biogene Gifte: Biologie-Chemie-Pharmakologie-Toxikologie, 3rd edn. Wissenschaftliche Verlagsgesellschaft $\mathrm{mbH}$, Stuttgart, p 962

3. Hickman DT, Rasmussen A, Ritz K, Birkett MA, Neve P (2020) Review: allelochemicals as multi kingdom plant defence compounds: towards an integrated approach. Pest Manag Sci 77:1121-1131. https://doi.org/ $10.1002 /$ ps.6076

4. Mithöfer A, Maffei ME (2017) General mechanisms of plant defence and plant toxins. In: Gopalakrishnakone P, Carlini C, Ligabue-Braun R (eds) Plant toxins. Springer, Dordrecht, pp 1-22. https://doi.org/10. 1007/978-94-007-6728-7_21-1

5. Hoerger CC, Wettstein FE, Bachmann HJ, Hungerbühler K, Bucheli TD (2011) Occurrence and mass balance of isoflavones and coumestrol on an experimental grassland field. Environ Sci Technol 45(16):6752-6760. https://doi.org/10.1021/es200567b

6. Hama JR, Strobel BW (2021) Occurrence of pyrrolizidine alkaloids in ragwort plants, soils and surface waters at the field scale in grassland. Sci Tot Environ 755:142822. https://doi.org/10.1016/j.scitotenv.2020. 142822

7. García-Jorgensen DB, Diamantopoulos E, Kisielius V, Rosenfield M, Rasmussen LH, Strobel BW, Hansen HCB (2021) Bracken growth, toxin production and transfer from plant to soil: a 2-year monitoring study. Environ Sci Eur. https://doi.org/10.1186/s12302-021-00484-0

8. Fastner J, Humpage A (2021) Hepatotoxic cyclic peptides-microcystins and nocularins. In: Chorus I, Welker M (eds) Toxic cyanobacteria in Water, 2nd edn. CRC Press, Boca Raton, pp 21-52

9. Schönsee CD, Bucheli TD (2020) Experimental determination of octanol-water partition coefficients of selected natural toxins. J Chem Eng Data 65(4):1946-1953. https://doi.org/10.1021/acs.jced.9b01129

10. Schönsee CD, Wettstein FE, Bucheli TD (2021) Disentangling mechanisms in natural toxin sorption to soil organic carbon. Environ Sci Technol 55(8):4762-4771. https://doi.org/10.1021/acs.est.0c06634

11. Günthardt BF, Hollender J, Hungerbühler K, Scheringer M, Bucheli TD (2018) Comprehensive toxic plants-phytotoxins database and its application in assessing aquatic micropollution potential. J Agric Food Chem 66(29):7577-7588. https://doi.org/10.1021/acs.jafc.8b01639

12. Jones MR, Pinto E, Torres MA, Dörr F, Mazur-Marzec H, Szubert K, Tartaglione L, Dell'Aversano C, Miles CO, Beach DG, McCarron P, Sivonen K, Fewer DP, Jokela J, Janssen EM-L (2020) Comprehensive database of secondary metabolites from cyanobacteria. Water Res 196:117017. https://doi.org/10.1016/j.watres.2021.117017

13. Paerl HW, Otten TG (2013) Harmful cyanobacterial blooms: causes, consequences, and controls. Microb Ecol 65:995-1010. https://doi.org/ 10.1007/s00248-012-0159-y

14. Hoerger CC, Wettstein FE, Hungerbühler K, Bucheli TD (2009) Occurrence and origin of estrogenic isoflavones in Swiss river waters. Environ Sci Technol 43(16):6151-6157. https://doi.org/10.1021/es901034u

15. Kolpin DW, Hoerger CC, Meyer MT, Wettstein FE, Hubbard LE, Bucheli TD (2010) Phytoestrogens and mycotoxins in lowa streams: an examination of under-investigated compounds in agricultural basins. J Environ Qual 39:2089-2099. https://doi.org/10.2134/jeq2010.0121

16. Bucheli TD, Wettstein FE, Hartmann N, Erbs M, Vogelgsang S, Forrer HR, Schwarzenbach RP (2008) Fusarium mycotoxins: overlooked aquatic micropollutants? J Agric Food Chem 56(3):1029-1034. https://doi.org/ 10.1021/jf073082k

17. Kolpin DW, Schenzel J, Meyer MT, Phillips PJ, Hubbard LE, Scott TM, Bucheli TD (2014) Mycotoxins: diffuse and point source contributions of natural contaminants of emerging concern to streams. Sci Total Environ 470-471:669-676. https://doi.org/10.1016/j.scitotenv.2013.09. 062

18. Schenzel J, Hungerbühler K, Bucheli TD (2012) Mycotoxins in the environment: II. Occurrence and origin in Swiss river waters. Environ Sci Technol 46(24):13076-13084. https://doi.org/10.1021/es301558v

19. Günthardt BF, Wettstein FE, Hollender J, Singer $\mathrm{H}$, Härri J, Hungerbühler K, Scheringer M, Bucheli TD (2021) Retrospective HRMS screening and dedicated target analysis reveal a wide exposure to pyrrolizidine alkaloids in small streams. Environ Sci Technol 55(2):1036-1044. https://doi. org/10.1021/acs.est.0c06411

20. Hama JR, Strobel BW (2019) Pyrrolizidine alkaloids quantified in soil and water using UPLC-MS/MS. RSC Adv 9:30350-30357. https://doi. org/10.1039/c9ra05301h 
21. Picardo M, Sanchis J, Nunez O, Farre M (2020) Suspect screening of natural toxins in surface and drinking water by high performance liquid chromatography and high-resolution mass spectrometry. Chemosphere 261:127888. https://doi.org/10.1016/j.chemosphere.2020. 127888

22. Tung KK, Chan CK, Zhao Y, Chan KKJ, Liu G, Pavlovic NM, Chan W (2020) Occurrence and environmental stability of aristolochic acids in groundwater collected from Serbia: links to human exposure and Balkan endemic nephropathy. Environ Sci Technol 54(3):1554-1561. https://doi. org/10.1021/acs.est.9b05337

23. Boleda R, Galceran T, Ventura F (2009) Monitoring of opitates, cannabinoids and their metabolites in wastewater, surface water and finished water in Catalonia, Spain. Water Res 43(4):1126-1136. https://doi.org/10. 1016/j.watres.2008.11.056

24. Buerge IJ, Kahle M, Buser HR, Müller MD, Poiger T (2008) Nicotine derivatives in wastewater and surface waters: application as chemical markers for domestic wastewater. Environ Sci Technol 42(17):6354-6360. https:// doi.org/10.1021/es800455q

25. Focazio MJ, Kolpin DW, Barnes KK, Furlong ET, Meyer MT, Zaugg SD, Barber LB, Thurman ME (2008) A national reconnaissance for pharmaceuticals and other organic wastewater contaminants in the United StatesII) untreated drinking water sources. Sci Total Environ 402(2-3):201-216. https://doi.org/10.1016/j.scitotenv.2008.02.021

26. Li S, Wen J, He B, Wang J, Hu X, Liu J (2020) Occurrence of caffeine in the freshwater environment: implications for ecopharmacovigilance. Environ Pollut 263:114371. https://doi.org/10.1016/j.envpol.2020.114371

27. Rodríguez-Gil JL, Cáceres N, Dafouz R, Valcárcel Y (2018) Caffeine and paraxanthine in aquatic systems: Global exposure distributions and probabilistic risk assessment. Sci Total Environ 612(15):1058-1071. https:// doi.org/10.1016/j.scitotenv.2017.08.066

28. Clauson-Kaas F, Ramwell C, Hansen HC, Strobel BW (2016) Ptaquiloside from bracken in stream water at base flow during storm events. Water Res 106:155-162. https://doi.org/10.1016/..watres.2016.09.049

29. Kisielius V, Hama JR, Skrbic N, Hansen HCB, Strobel BW, Rasmussen LH (2020) The invasive butterbur contaminates stream and seepage water in groundwater wells with toxic pyrrolizidine alkaloids. Nat Sci Rep Sci Rep 10:19784. https://doi.org/10.1038/s41598-020-76586-1

30. Visser PM, Verspagen JM, Sandrini G, Stal LJ, Matthijs HC, Davis TW et al (2016) How rising $\mathrm{CO}_{2}$ and global warming may stimulate harmful cyanobacterial blooms. Harmful Algae 54:145-159. https://doi.org/10.1016/j. hal.2015.12.006

31. Sanseverino I, Antonio DC, Loos R, Lettieri T (2017) Cyanotoxins: methods and approaches for their analysis and detection. Publications Office of the European Union, Luxembourg. https://doi.org/10.2760/36186

32. WHO (2020) Cyanobacterial toxins: anatoxin-a and analogues; cylindrospermopsins; microcystins; saxitoxins. Background documents for development of WHO guidelines for drinking-water quality and guidelines for safe recreational water environments. WHO, Geneva

33. Kaltner F, Rychlik M, Gareis M, Gottschalk C (2020) Occurrence and risk assessment of pyrrolizidine alkaloids in spices and culinary herbs from various geographical origins. Toxins 12(3):155. https://doi.org/10.3390/ toxins 12030155

34. Lucchetti MA, Glauser G, Kilchenmann V, Dübecke A, Beckh G, Praz C, Kast C (2016) Pyrrolizidine alkaloids from Echium vulgare in honey originate primarily from floral nectar. J Agric Food Chem 64(25):5267-5273. https:// doi.org/10.1021/acs.jafc.6b02320

35. Mulder PPJ, Sánchez PL, These A, Preiss-Weigert A, Castellari M (2015) Occurrence of pyrrolizidine alkaloids in food. EFSA Support Publ 12(8):859E. https://doi.org/10.2903/sp.efsa.2015.EN-859

36. Rockström J, Steffen W, Noone K, Persson Å et al (2009) A safe operating space for humanity. Nature 461(24):472-475. https://doi.org/10.1038/ 461472a

37. Boller B (1996) Formica, ein Mattenklee mit reduziertem Östrogengehalt. Agrarforsch 3(10):486-488

38. Jørgensen K, Bak S, Busk PK, Sørensen C, Olsen CE, Puonti-Kaerlas J, Møller BL (2005) Cassave plants with a depleted cyanogenic glucoside content in leaves and tubers. Distribution of cyanogenic glucosides, their site of synthesis and transport, and blockage of the biosynthesis by RNA interference technology. Plant Phys 139(1):363-374. https://doi.org/10.1104/ pp. 105.065904
39. Love HK, Rakow G, Raney JP, Downey RK (1990) Development of low glucosinolate mustard. Can J Plant Sci 70(2):419-424. https://doi.org/10. 4141/cjps90-049

40. DiTomaso JM, Kyser GB, Oneto SR, Wilson RG, Orloff SB et al (2013) Weed control in natural areas. University of California-Weed Research and Information Center, Berkeley, p 544

41. Leiss KA (2011) Management practices for control of ragwort species. Phytochem Rev 10:153-163. https://doi.org/10.1007/s11101-010-9173-1

42. Stewart GB, Pullin AS, Tyler C (2007) The effectiveness of asulam for bracken (Pteridium aquilinum) control in the United Kingdom: a meta-analysis. Environ Manag 40(5):747-760. https://doi.org/10.1007/ s00267-006-0128-7

43. Jiang X, Strobel BW, Cedergreen N, Hansen HCB (2019) Stability of aponin biopesticides: hydrolysis in aqueous solutions and lake waters. Environ Sci Process Impact 21:1204-1214. https://doi.org/10.1039/C9EM00012G

44. Marcantionio CD, Bertelkamp C, van Bel N, Pronk TE, Timmers PHA, van der Wielen P, Brunner AM (2020) Organic micropollutant removal in full-scale rapid sand filters used for drinking water treatment in The Netherlands and Belgium. Chemosphere 260:127630. https://doi.org/10. 1016/j.chemosphere.2020.127630

45. Schneider M, Rataj R, Kolb JF, Blaha L (2020) Cylindrospermopsin is effectively degraded in water by pulsed corona-like and dielectric barrier discharges. Environ Pollut 266:115423. https://doi.org/10.1016/j.envpol. 2020.115423

46. Skrbic N, Pedersen A-K, Christensen SCB, Hansen HCB, Rasmussen LH (2020) A novel method for determination of the natural toxin ptaquiloside in ground and drinking water. Water 12(10):2852. https://doi.org/10. 3390/w12102852

47. Li J, Persson KM, Pekar H, Jansson D (2021) Evaluation of indicators for cyanobacterial risk in 108 temperate lakes using 23 years of environmental monitoring data. Environ Sci Eur 33:54. https://doi.org/10.1186/ s12302-021-00483-1

48. Filatova D, Jones MR, Haley JA, Nunez O, Farre M, Janssen EM-L (2021) Cyanobacteria and their secondary metabolites in three freshwater reservoirs in the United Kingdom. Environ Sci Eur 33:29. https://doi.org/ 10.1186/s12302-021-00472-4

49. Natumi R, Marcotullio S, Janssen EM-L (2021) Phototransformation kinetics of cyanobacterial toxins and secondary metabolites in surface waters. Environ Sci Eur 33:26. https://doi.org/10.1186/s12302-021-00465-3

50. Lovin LM, Kim S, Taylor RB, Scarlett KR, Langan LM, Chambliss CK, Chatterjee S, Scott JT, Brooks BW (2021) Differential influences of ( \pm ) anatoxin-a on photolocomotor behavior and gene transcription in larval zebrafish and fathead minnows. Environ Sci Eur 33:40. https://doi.org/10.1186/ s12302-021-00479-x

51. Kubickova B, Ramwell C, Hilscherova K, Jacobs MN (2021) Highlighting the gaps in hazard and risk assessment of unregulated endocrine active substances in surface waters: retinoids as a European case study. Environ Sci Eur 33:20. https://doi.org/10.1186/s12302-020-00428-0

52. Keliri E, Paraskeva C, Sofokleous A, Sukenik A, Dziga D, Chernova E, Brient L, Antoniou MG (2021) Occurrence of a single-species cyanobacterial bloom in a lake in Cyprus: monitoring and treatment with hydrogen peroxide-releasing granules. Environ Sci Eur 33:31. https://doi.org/10. 1186/s12302-021-00471-5

53. Schneider M, Bláha L (2020) Advanced oxidation processes for the removal of cyanobacterial toxins from drinking water. Environ Sci Eur 32:94. https://doi.org/10.1186/s12302-020-00371-0

54. Wu JS, Clauson-Kaas F, Lindqvist DN, Rasmussen LH, Strobel BW, Hansen HCB (2021) Does the natural carcinogen ptaquiloside degrade readily in groundwater? Environ Sci Eur 33:24. https://doi.org/10.1186/ s12302-021-00468-0

55. Schönsee CD, Wettstein FE, Bucheli TD (2021) Phytotoxin sorption to clay minerals. Environ Sci Eur 33:36. https://doi.org/10.1186/ s12302-021-00469-z

56. Hama JR, Strobel BW (2020) Natural alkaloids from narrow-leaf and yellow lupins transfer to soil and soil solution in agricultural fields. Environ Sci Eur 32:126. https://doi.org/10.1186/s12302-020-00405-7

57. Nanusha MY, Krauss M, Brack W (2020) Non-target screening for detecting the occurrence of plant metabolites in river waters. Environ Sci Eur 32:130. https://doi.org/10.1186/s12302-020-00415-5 
58. Nanusha MY, Krauss M, Schönsee CD, Günthardt BF, Bucheli TD, Brack W (2020) Target screening of plant secondary metabolites in river waters by liquid chromatography coupled to high-resolution mass spectrometry (LC-HRMS). Environ Sci Eur 32:142. https://doi.org/10.1186/ s12302-020-00399-2

59. Nanusha MY, Krauss M, Strobel BW, Sørensen BG, Schulze T, Brack W (2021) Occurrence of plant secondary metabolite fingerprints in river waters from Eastern Jutland, Denmark. Environ Sci Eur 33:25. https://doi. org/10.1186/s12302-021-00464-4

60. Skrbic N, Kisielius V, Pedersen A-K, Christensen SCB, Hedegaard MJ, Hansen HCB, Rasmussen LH (2020) Occurrence of carcinogenic illudane glycosides in drinking water wells. Environ Sci Eur 33:44. https://doi.org/ 10.1186/s12302-021-00486-y

61. Griffiths MR, Strobel BW, Hama JR, Cedergreen N (2021) Toxicity and risk of plant-produced alkaloids to Daphnia magna. Environ Sci Eur 33:10. https://doi.org/10.1186/s12302-020-00452-0

62. Escher BI, van Daele C, Dutt M, Tang JYM, Altenburger R (2013) Most oxidative stress response in water samples comes from unknown chemicals: the need for effect-based water quality trigger values. Environ Sci Technol 47(13):7002-7011. https://doi.org/10.1021/es304793h

63. Tousova Z, Oswald P, Slobodnik J, Blaha L et al (2017) European demonstration program on the effect-based and chemical identification and monitoring of organic pollutants in European surface waters. Sci Total Environ 601-602:1849-1868. https://doi.org/10.1016/j.scitotenv.2017.06. 032

64. Altenburger R, Brack W, Burgess RM, Busch W, Escher BI, Focks A, Hewitt LM et al (2019) Future water quality monitoring: improving the balance between exposure and toxicity assessments of real-world pollutant mixtures. Environ Sci Eur 31:12. https://doi.org/10.1186/s12302-019-0193-1

65. Brack W, Aissa SA, Backhaus T, Dulio V, Escher BI, Faust M, Hilscherová K et al (2019) Effect-based methods are key. The European collaborative project SOLUTIONS recommends integrating effect-based methods for diagnosis and monitoring of water quality. Environ Sci Eur 31:10. https:// doi.org/10.1186/s12302-019-0192-2

66. Atanasov AG, Zotchev SB, Dirsch VM, Supuran CT (2021) Natural products in drug discovery: advances and opportunities. Nature Rev 20:200-216. https://doi.org/10.1038/s41573-020-00114-z

67. Dayan FE, Duke SO (2014) Natural compounds as next-generation herbicides. Plant Phys 166(3):1090-1 105. https://doi.org/10.1104/pp.114. 239061

68. Dalu T, Wasserman RJ, Jordaan M, Froneman WP, Weyl OLF (2015) An assessment of the effect of rotenone on selected non-target aquatic fauna. PLoS ONE 10(11):e0142140. https://doi.org/10.1371/journal.pone. 0142140

69. Duke SO, Dayan FE, Rimando AM, Schrader KK, Aliotta G, Oliva A, Romagni JG (2002) Chemicals from nature for weed management. Weed Sci 50(2):138-151

70. Petroski RJ, Stanley DW (2009) Natural compounds for pest and weed control. J Agric Food Chem 57(18):8171-8179. https://doi.org/10.1021/ jf803828w

71. Vyvyan JR (2002) Allelochemicals as leads for new herbicides and agrochemicals. Tetrahedron 58(9):1631-1646. https://doi.org/10.1016/S00404020(02)00052-2

72. Venter HJ, Böhn T (2016) Interactions between Bt crops and aquatic ecosystems: a review. Environ Toxicol Chem 35(12):2891-2902. https:// doi.org/10.1002/etc.3583

73. Kaya E, Karahan S, Bayram R, Yaykasli KO, Colakoglu S, Saritas A (2015) Amatoxin and phallotoxin concentration in Aminita phalloides spores and tissues. Toxicol Ind Health 31(12):1172-1177. https://doi.org/10.1177/ 0748233713491809

74. Baldoni AB, de Carvalho MH, Sousa NL, de Medeiros Nobrega MB, Milani M, Aragao FJL (2011) Variability of ricin content in mature seeds of caster bean. Pesq Agrop Bras 46(7):776-779. https://doi.org/10.1590/S0100204X2011000700015
75. Lopez TA, Cid MS, Bianchini ML (1999) Biochemistry and hemlock (Conium maculatum L.) alkaloids and their acute and chroic toxicity in livestock. A review. Toxicon 37(6):841-865. https://doi.org/10.1016/s00410101(98)00204-9

76. Omayio DG, Abong GO, Okoth MW (2016) A review of occurence of glycoalkaloids in potato and potato products. Cur Res Nutr Food Sci 4(3):195-202. https://doi.org/10.12944/CRNFSJ.4.3.05

77. Deng NL, Overk CS, Yao P, Totura S, Deng Y, Hedayat AS, Bolton JL, Pauli GF, Farnsworth NR (2006) Seasonal variation of red clover (Trifolium pratense L., Fabaceae) isoflavones and estrogenic activity. J Agric Food Chem 54(4):1277-1282. https://doi.org/10.1021/jf052927u

78. Sornyotha S, Kyu KL, Ratanakhanokchai K (2007) Purification and detection of linamarin from cassava root cortex by high performance liquid chromatography. Food Chem 104(4):1750-1754. https://doi.org/10. 1016/j.foodchem.2006.10.071

79. Smith BL, Seawright AA, Ng JC, Hertle AT, Thomson JA, Bostock PD (1994) Concentration of ptaquiloside, a major carcinogen in bracken fern (Pteridium spp.), from eastern Australia and from a cultivated worldwide collection held in Sydney, Australia. Nat Toxins 2(6):347-353. https://doi. org/10.1002/nt.2620020602

80. Watanabe MF, Watanabe M, Kato T, Harada K-I, Suzuki M (1991) Composition of cyclic peptide toxins among strains of Microcystis aeruginosa (blue-green algae, cyanobacteria). Bot Mag Tokyo 104:49-57. https://doi. org/10.1007/BF02493403

81. Velzeboer RMA, Baker PD, Rositano J, Hersztyn T, Codd GA, Raggett SL (2000) Geographical patterns of occurence and composition of saxitoxins in the cyanobaterial genus Anabaena (Nostocales, Cyuanophyta) in Australia. Phycol 39:395-407. https://doi.org/10.2216/i0031-8884-39-5-395.1

82. Rasmussen LH, Hansen HCB, Lauren D (2005) Sorption, degradation and mobility of ptaquiloside, a carcinogenic Bracken (Pteridium sp.) constituent, in the soil environment. Chemosphere 58(6):823-835. https://doi. org/10.1016/j.chemosphere.2004.08.088

83. McCord J, Lang JR, Hill D, Strynar M, Chernoff N (2018) pH dependent octanol-water partitioning coefficients of microcystin congeners. J Water Health 16(3):340-345. https://doi.org/10.2166/wh.2018.257

84. He X, McMahon S, Henderson TD II, Griffey SM, Cheng LW (2010) Ricin toxicokinetics and its sensitive detection in mouse sera or feces using immuno-PCR. PLoS ONE 5(9):e12858. https://doi.org/10.1371/journal. pone. 0012858

85. Lee ST, Green BT, Welch KD, Pfister JA, Panter KE (2008) Stereoselective potencies and relative toxicities of coniin enantiomers. Chem Res Toxicol 21(10):2016-2064. https://doi.org/10.1021/t×800229w

86. Medjakovic S, Jungbauer A (2008) Red clover isoflavones biochanin A and formononetin are potent ligands of the human aryl hydrocarbon receptor. J Steroid Biochem Mol Biol 108(1-2):171-177. https://doi.org/ 10.1016/j.jsbmb.2007.10.001

87. WHO (2020) Cyanobacterial toxins: saxitoxins. Background document for development of WHO Guidelines for drinking-water quality and guidelines for safe recreational water environments. WHO, Geneva, p 24

88. Fawell JK, James CP, James HA (1994) Toxins from blue-green algae: toxicological assessment of Microcystin-LR and a method for its determination in water. Water Research Centre, Medmenham

89. Zurawell R, Chen H, Burke J, Prepas EE (2005) Hepatotoxic cyanobacteria: a review of the biological importance of microcystins in freshwater environments. J Toxicol Environ Health B 8:1-37. https://doi.org/10.1080/ 10937400590889412

\section{Publisher's Note}

Springer Nature remains neutral with regard to jurisdictional claims in published maps and institutional affiliations. 